\title{
Depth of Women's Involvement in National Special Program for Food Security in Niger state, Nigeria
}

\author{
M.S. Sadiq*, Mohammed Abubakar and T.L.Yusuf.* \\ *Department of Agric. Economics and Extension Techn., Federal University of Tech.,Minna, Nigeria.
}

\begin{abstract}
The study evaluates women's involvement in National Special Programme for Food Security in Niger State Nigeria. Purposive sampling technique was used to select participants from the three Agricultural sites of the programme using structured interview schedule to gather information from one hundred and three respondents. Descriptive statistics, Likert scale and t-test were used to analyse the data collected. Results emerging from analyzed data indicated that $55.9 \%$ of the women participated in crop production which led to increase in their farm size, output and income. Women's participation was low in marketing 13.7\%) and fairly high in livestocks (30.2\%). The study also indicted that respondents expressed satisfaction interms of involvement in the implementation of NSPFS programme components identified. Loans provided for the project participants assisted the recipients in boosting their farm production. The t-test result revealed that significant increases were found in the farm size, output and income of participants after the programme. This means that the programme has impacted positively on the participants especially in Agricultural production. The study concluded that women participation in NSPFS programme actually reduced poverty level and significantly contributed to food security. This has given them more access to production credit and other specific benefits. It has increased their output, improved their living condition. It was recommended that the programme should have more sites and participants so as to better raise their output, income and farm size.
\end{abstract}

Keywords: Food security, Poverty alleviation, Farm size, Income, Output

\section{Introduction}

Food security is currently both a fundamental objective and an expected outcome of development policies in Nigeria, as the country currently faces a challenge in meeting the basic food needs of its population. The majority of Nigerians depend largely on subsistence agriculture, which is hardly sufficient to meet the food needs of the population. However, notwithstanding the many policies, programs, and investments by various local and international agencies operating in the country, food security and the nutrition situation are worsening (FEWSNET 2007). In Nigeria, women and female-headed households are frequently the most chronically poor within rural communities. Though women play significant roles in rural economic activities, women have lower social status than men and consequently less access to schooling and training, particularly in childcare and health practices. While the number of men migrating from rural areas in search of employment has increased over the last decades, the number of female-headed households has risen substantially. Women struggle to cope as the burden of work at home and in the fields, fall on their shoulders. Malnutrition is a frequent problem in these households. In order to better integrate women into the socioeconomic life of Nigeria, education and employment opportunities must be improved and women should be encouraged to participate more actively in development activities (IFAD 2006). Women are the key to food and nutrition security (Quisumbing 1995; Ukeje 2003). They play an important role as producers of food, as managers of natural resources, in income generation and as providers of care for their families. Yet, women in Nigeria often continue to have limited access to land, education, credit, information, technology, and decision making bodies. The control of land confers on the owner access to credit, and access to inputs such as agricultural extension service, seeds, modern irrigation systems, fertilizers, pesticides, and membership of cooperative societies. Without land, the women have no security and have to depend on landowners for employment. In the eastern part of the country where the population density is high, the break-up of communal land holdings has led to the transfer of exclusive land rights to male-headed households (Ukeje 2003). This ignores both the existence of female-headed households and the rights of married women to a joint share. Women are either dependent on the goodwill of their husbands and the availability of land to grow food or have to lease farmland.

The problem of food and nutrition security in Nigeria has not been adequately and critically analyzed, despite various approaches addressing the challenge. The enormous amount of money spent in attempting to ensure the food security of Nigerians without success calls for a fundamental review of the past approaches and achievements to see what lessons can be learned to re-strategize and to develop an approach that will ensure that better progress is made toward achieving the first Millennium Development Goal (Sanusi et.al.,2006). Since the majority of Nigerians (70 percent) live in rural areas, an analysis of the food and nutrition security status of rural dwellers will provide a clear picture of what needs to be done to ensure food security in Nigeria with the 
attendant improvements in nutrition status when all the other necessary conditions, such as adequate health and care, are present.

And as a first step towards the Millennium Development goals target of reducing by half the number of hungry people by 2015, the Federal Government of Nigeria operated a pilot project of the NSPFS in 3 sites of Kano State (FGN, 2006). Based on the successful experience, a five year nationwide National Special Programme for Food Security (NSPFS) was launched in 2001 with the objective to increase and stabilise food production rapidly and sustainable through the wide spread dissemination of improved technologies and management practices in areas with high potential, and to create an economic and social environment conducive to food production as well as reaching some 30,000 farming families in each selected areas (FGN, 2006).

The study was designed to evaluate the level of women's involvement in NSPFS in Niger State. Specifically, the study will;

1. identify the various project which women participate;

2. assess the level of women participation in different projects;

3. identify specific benefits of the programme that accrued to the participants; and

4. compare the farmsize, output and income of participants before and after participation in the programme.

\section{Research Hypotheses}

Based on the objectives of the study, the following hypothesis was postulated.

Ho1: There is no significant difference between the participants' farm size, outputs, and incomes before and after their participation in the NSPFS programme.

\section{Methodology}

Niger state is located in north central Nigeria and its the largest state in the country in terms of landmass. The state is bordered in the north by Zamfara state, east by 'Kebbi, and federal capital territory border the state at both north-east and south-east. It shares a common boundary with the republic of Benin at Babanna in Borgu local government area (ADP, 2008). Niger state lies in the guinea savannah vegetation of the country with favourable climate condition for crops and livestock production. The state has total population of $3,950,249$ and about $85 \%$ of the state population are farmers'. Only about $15 \%$ are involve in other activities such as white-collar jobs, business e.t.c. (NPC, 2006).Purposive sampling technique was used to select a total of 103 respondents from women strata in the three sites of the programme in the state, namely; Nasarawa (zone I), Gidan Mangoro (zone II), and Lioji (zone III). Secondly, each site was stratified into two and the female strata which is the focal point of study was selected for the study. Three female groups with its membership ranging from 15 to 20 were identified in each site. A scale of $60 \%$ was used to select the number of respondents for the study. Lastly, 34, 35 and 34 were randomly selected from Nasarawa, Gidan Mangoro, Lioji sites respectively, thus, given a total sample size of one hundred and three (103) respondents for the study. Structured intrerview schedule was used to elicit informations from the respondents. Descriptive statistics, likert scale and $\mathrm{t}$-test were used to analyse the data collected.

\section{Various Projects which Women Participated In}

\section{Results And Discussion}

Table 1 shows that majority of the respondents participated in crop production $(55.9 \%)$ while $(30.2 \%)$ participated in livestock production. Marketing (13.7\%) have the least number of participant. This implies that arable farming is the enterprise which women mostly participated in, as such NSPFS needs to enlighten them on the importance of enterprises diversification thereby remain active in economic ventures throughout the year since crop production is seasonal (Rainfed agriculture).

Table 1.Distribution of Respondents According to Various Projects.

\begin{tabular}{|lcc|}
\hline Enterprises & Frequency & Percentage \\
\hline Livestock's & & \\
Cattle fattening & 21 & 5.9 \\
Poultry & 18 & 5.0 \\
Goat fattening & 51 & 14.3 \\
Sheep fattening & 18 & 5.0 \\
Crops & & \\
Vegetable & 23 & 6.4 \\
Yam & 9 & 2.5 \\
Rice & 58 & 16.2 \\
Maize & 77 & 21.5 \\
\hline
\end{tabular}




\begin{tabular}{|c|c|c|}
\hline Groundnut & 33 & 9.3 \\
\hline Agribusiness & & \\
\hline Marketing & 49 & 13.9 \\
\hline Total & $357 *$ & 100 \\
\hline
\end{tabular}

Source: field survey, 2012.

Note: * implies that multiple responses were recorded.

\section{Participation Level of the Respondents Involvement in Project Implementation}

Table 2 reveals that the level of women participation in the NSPFS programme components identified is satisfactory. These components of evaluation were identification $(\overline{\mathrm{x}}=1.2)$, planning $(\overline{\mathrm{x}}=1.2)$, decision making $(\overline{\mathrm{x}}=1.1)$, and implementation $(\overline{\mathrm{x}}=1.3)$. This implies that the beneficiaries were involved in the implementation of all aspect of the programme. According to Ayoola (2001), project implementation has always been the bane to agricultural development in Nigeria.

Table 2. Mean Satisfaction Level Scores of Involvement in Project Implementation.

\begin{tabular}{|lcccccc|}
\hline Components & HI(2) & MI(1) & LI(0) & Weighted sum & Mean & Involvement level \\
\hline Identification & 43 & 40 & 20 & 126 & 1.2 & HI \\
Planning & 42 & 37 & 24 & 121 & 1.2 & HI \\
Decision making & 38 & 35 & 30 & 111 & 1.1 & HI \\
Implementation & 53 & 33 & 17 & 139 & 1.3 & HI \\
\hline
\end{tabular}

Source: field survey, 2012.

$\mathrm{HI}=$ Highly involved $; \mathrm{MI}=$ Moderately involved; $\mathrm{LI}=$ lowly involved

\section{Specific Benefits that accrued to the Participants'}

Table 3 reveals the specific benefits derived by the respondents. These benefits were grouped into four categories. $33.9 \%$ of the respondents derived benefits from subsidized agro-chemicals given to them, $22.1 \%$ of the respondents derived benefit from loan, $26.5 \%$ derived benefit in terms of extension contact, $13.6 \%$ interms of good marketing information, while 3.9\% derived benefit from processing facilities given. This indicates a good overall performance of the NSPFS interms of impact on the target. This findings is in conformity with that of Adekoya et al.(2000).

Table 3. Distribution of Respondents by Specific Benefits Derived

\begin{tabular}{|lcc|}
\hline Benefits & Frequency & Percentage \\
\hline Loan & 86 & 22.1 \\
Processing facilities & 15 & 3.9 \\
Marketing information & 53 & 13.6 \\
Access to extension service & 103 & 26.5 \\
Fertilizer & 53 & 13.6 \\
Improved seed & 41 & 10.5 \\
Insecticide & 15 & 3.9 \\
Herbicide & 23 & 5.9 \\
Total & $\mathbf{3 8 9 *}$ & $\mathbf{1 0 0}$ \\
\hline
\end{tabular}

Note: $*$ implies that multiple respondent was recorded.

Source: field survey, 2012

Farm Size, Output and Income Level Before and After Participation in The Programme.

Table 4 indicates the level of farm size, output and income level of the participant before and after the programme. The t-value (-3.542) of the farm size before and after participation in the programme is significant at $1 \%$. This implies that the participant's involvement in NSPFS enabled them to expand their farm size as a result of loan received and accessibility to other benefits of the programme. The t-value (-5.258) in the outputs of crops before and after participation in the programme is significant at $1 \%$. This indicates that the participant's had higher yield after participating in the programme, which implies that participant's judiciously utilized the loan obtained from the programme coupled with increased farm size to increase agricultural yield. The $t$-value $(-8.121)$ in the output of livestock before and after the participating in the programme is significant at $1 \%$. This implies that the participant's involvement in NSPFS enabled them to increase their livestocks' size as a result of loan received and accessibility to other benefits of the programme.Lastly, t-value (12.611) in income level before and after participating in the programme is significant at $1 \%$. This implies that participation in the 
programme enables the participants' to generate more income from higher output. This increase in income will reduce poverty level, thereby, improving their livelihood status.

Table 4. Distribution of the Respondents Farm Size, Output and Income Level Before and After their Participation in the Programme.

\begin{tabular}{|lc|}
\hline Parameter & t-test \\
\hline Farm size before in hectares/farm size after in hectares & $-3.542^{* * * *}$ \\
Outputs of crops before in kg/output of crops after in kg & $-5.258^{* * *}$ \\
Outputs of livestock before/Output of livestock after & $-8.121^{* * *}$ \\
Income before/income after & $-12.611^{* * *}$ \\
\hline
\end{tabular}

Source: field survey, 2012

Note: $* * * * * *$ implies $1 \%, 5 \%$ and $10 \%$ level of significance

\section{Hypothesis Testing Results}

Ho1: There is no significant difference in the farmsize, output and income of participants before and after participation in the programme

It was expected that the participants farm size, output and income, would increase after the programme. The ttest analysis was carried out to ascertain whether there is any significant increase to the farm size, output and income. The calculated t-ratio exceeds the tabulated t-ratio at 0.01 level of significance. Therefore there is a significant increase in the participant farm size output and income after the programme.

\section{Conclusion}

Poverty reduction and food security in Niger State have proved to be of immense challenge not only to the state but the nation as a whole. The study focused on women because of the significant role they play in the overall welfare of their families. The study makes the following conclusions on the basis of the findings of the study. women's participation has significantly improved their welfare status. Loans provided for the project participants assisted the recipients in boosting their farm production as a result of increased in farm size cultivated. Significant improvements were found in the farm size, output and income of participants after the programme.

\section{Recommendations}

Based on the results of the study, it is therefore recommended that:

(1) The programme should be expanded to cover more areas, thus increasing the number of sites and participants. This would also extend the benefits of the programme to more people.

(2) Participants should be encouraged to utilize their loans judiciously and possibly be given more training along with the loan to have maximum returns.

\section{Reference}

[1]. Adekoya, A., Onifade, F.A. and Oladele, O.I. (2000). Awareness and Participation in Family Support Programme Activities in Oyo State. Proceedings of 10th Annual Conference oftheNigerianRural Sociological Association, Obafemi Awolowo University,Ile-Ife. pp. 122-127.

[2]. Ayoola GB (2001). Essays on the Agricultural Economy: A Book of Readings onAgricultural Policy and Administration in Nigeria. Ibadan, Nigeria: TMA Publishers.

[3]. Federal Government of Nigeria, (2003). National Assessment Report, Sustainable Development in Nigeria, Vol. 11(2): 5. Abuja, Nigeria

[4]. IFAD (International Fund for Agricultural Development. (2006). Annual Report. Rome:International Fund for Agricultural Development.

[5]. Quisumbing, A. R., L. R. Brown, H. S. Feldstein, L. Haddad, and C. Pena. (1995). Women:The key to food security. Food Policy Statement No. 21. Washington, DC: International Food Policy Research Institute.

[6]. Sanusi R. A., and B. C. Adebukola and Y. B. Oyindamola.( 2006). Measuring household food insecurityin selected local government areas of Lagos and Ibadan, Nigeria. Pakistan Journal of Nutrition 5 (1): 62-67.

[7]. Ukeje E. (2003). Modernizing small holder agriculture to ensure food security and genderempowerment: Issues and policy. http://www.g24.org/ukeje.pdf. (accessed August 2008) 